\title{
PREPRINT
}

to be published in 2019 in Encyclopedia of Ocean Sciences, 3rd Edition/

Earth Systems and Environmental Sciences, Volume

$\mathrm{https://doi.org/10.1016/B978-0-12-409548-9.11368-5}$

\section{Millennial-Scale Ocean Climate Variability}

\author{
Antje Voelker ${ }^{1,2}$ and J.T. Andrews ${ }^{3}$ \\ 1. Instituto Português do Mar e da Atmosfera (IPMA); Divisão de Geologia e Georecursos Marinhos; Rua \\ Alfredo Magalhães Ramalho 6; 1495-006 Lisboa; Portugal \\ 2. Centro de Ciências do Mar (CCMAR); Universidade do Algarve; Campus de Gambelas; 8005-139 \\ Faro; Portugal. ORCID 0000-0001-6465-6023. antje.voelker@ipma.pt \\ 2. INSTAAR asnd Department of Geological Sciences, University of Colorado, Boulder, USA. ORCID: \\ 0000-0003-3169-5979. andrewsj@colorado.edu
}

\author{
Keywords: \\ Dansgaard-Oeschger events \\ Heinrich events \\ Ice-rafted debris \\ Laurentide Ice Sheet \\ Atlantic Meridional Overturning Circulation \\ Bipolar seesaw \\ Hydrological cycle \\ Marine productivity
}

\begin{abstract}
Marine sediment cores that span the last 50,000 years frequently show considerable variability in sediment and biogeochemical variables. In the North Atlantic, a series of massive iceberg and meltwater events (Heinrich events) were sourced from Hudson Strait and the Laurentide Ice Sheet with a periodicity of $\sim 7.2 \mathrm{ky}$ and had significant impacts on the Atlantic meridional overturning circulation and the global hydrological and biogeochemical cycles. Some marine proxies show higher frequency, abrupt events, that may match the Dansgaard-Oeschger (D-O) oscillations. Predictable millennial-scale periodicities and associated forcings have proved elusive, and an observed $\sim 1.5$ ky cycle may be linked to stochastic resonance.
\end{abstract}

\section{Introduction}

Analysis of Quaternary marine sediment cores has changed in emphasis over the last four decades. In particular, this has involved a change in focus from variations in proxy records on Milankovitch timescales (with recurring periodicities of c. 20,000, 40,000, and 100,000 years), to a focus on millennial-to multi-decadal scale variability, often marked by a rapid or abrupt shift from one climate state to another. This shift in focus has been driven by several factors, in particular the ability to date small $(<4 \mathrm{mg})$ samples of foraminifera and the recovery of marine sediment cores that exhibit high rates of sediment accumulation $\left(>10 \mathrm{~cm} \mathrm{ky}^{-1}\right)$. The term 'millennial-scale climate variability' includes events with periods of between 1000 and 10,000 years, the recognition of which dates from the late 1980s and the 1990s, when studies documented and were able to date a series of abrupt iceberg rafting events (Heinrich events), originating from the Hudson Strait ice stream and the Laurentide Ice Sheet. 
Evidence for abrupt, millennial-scale changes in ocean sediments has resulted in a paradigm shift. The role of the oceans in abrupt climate forcing is now considered to be paramount, whereas under the Milankovitch scenario the role of the oceans was frequently considered subordinate to changes on land associated with the growth and decay of the large Quaternary ice sheets, principally driven by changes in high-latitude, Northern Hemisphere insolation. The rationale for conducting high-resolution, millennial-scale studies of marine sediments was initially driven by the need to ascertain whether the abrupt climate changes recorded in the polar ice sheet records, particularly the millennial-scale Dansgaard-Oeschger (D-O) events (Fig. 1a), were evident in the ocean system. However, with documented changes in the present-day Global Climate System, the rationale for high-resolution marine climate studies is more focused on providing records for the past 1 to 10 millennia to serve as a baseline for policy decisions and as "hindcasts" for the evaluation of the accuracy of computer climate simulations.

\section{History}

The ability to undertake millennial-scale climate reconstructions from marine sediments was conditioned by several requirements, which could not be met until the 1980s and early 1990s. An underlying rationale for this interest were the results from the Greenland and Antarctic ice core records which showed remarkably abrupt oscillations in a variety of proxies for the last 40,000-80,000 years (Fig. 1a, h). The advent of accelerator mass spectrometry (AMS) ${ }^{14} \mathrm{C}$ dating of small $(2-10 \mathrm{mg})$ samples of foraminifera allowed many of the world's deep-sea and shelf sediments to be directly dated up to a limit of between 30,000 and 50,000 years ago. Because of the small sample size required and the relatively fast turnaround, it became possible to obtain many dates on cores, and in some cases the resolution approached several dates per millennium. This technology also meant that sediment cores from environments with high rates of sediment accumulation could be successfully dated. Therefore, a variety of sediment environments from the 'drifts' around the North Atlantic, to glaciated shelves and fiords, could now be studied. In these environments, sediment accumulation rates (SARs) were often greater than $20 \mathrm{~cm} \mathrm{ky}^{-1}$ and could reach rates as high as $300 \mathrm{~cm} \mathrm{ky}^{-1}$. In areas with these very high rates of sediment accumulation there was a need for improved coring technology; giant piston corers were thus developed, with recoveries in the range of 20-60 m, such as the Calypso system deployed from the French research vessel Marion Dufresne. This allowed for very high-resolution studies (SAR of $\geq 1 \mathrm{~m} \mathrm{ky}^{-1}$, decadal resolution) if the cores recovered sediments with basal dates of $10000 \mathrm{y}$ before present (BP). If the cores were extracted from areas with more modest rates of sediment accumulation $(>10$ and $<100 \mathrm{~cm}$ $\mathrm{ky}^{-1}$ ), then millennial-scale studies would have been possible.

However, a problem with longer temporal records was that they recovered sediments with ages greater than the radiocarbon limit of c. $45 \mathrm{ka}$. Records that extended back into marine or oxygen isotope stages 4 and 5 cannot be radiocarbon dated, but their chronology has to be derived by correlation with other records. In important but rare cases, the marine sediment is annually laminated and a chronology can be developed by counting the varves. Volcanic shards recovered from polar ice sheets can be matched with tephras in nearby marine cores thus establishing both comparable chronologies and age estimates. However, a severe limitation on an understanding of leads and lags between various ocean climate records is the geographic and temporal variability in the ocean reservoir correction, which can amount to $100 \mathrm{~s}$ if not $1000 \mathrm{~s}$ of years. If rates of sedimentation are slow $(<8 \mathrm{~cm} / \mathrm{ky})$, bioturbation can result in significant offsets between the true and estimated ages of millennial-scale proxies. 


\section{Examples of Millennial-scale Oceanographic Proxy Records}

In recent decades, the number of papers on millennial-scale ocean variability has increased substantially. The most-documented proxies for millennial changes in ocean climate and hydrography are: (1) changes in the non-carbonate sand size $(<2000$ and $>63 \mu \mathrm{m})$ fraction, the so-called iceberg-rafted detrital (IRD) fraction (Fig. 1b); (2) changes in the $\delta^{18} \mathrm{O}$ of planktonic and benthic foraminifera which reflect combined changes in the global ice volume (Fig. 1f), temperature, and meltwater volume; (3) changes in the $\delta^{13} \mathrm{C}$ of marine carbonates, which is a measure of productivity and water mass history, and is used to trace variations in the production and circulation patterns of bottom water (Fig. 1e); (4) changes in the composition of faunas or floras which reflect the response of the biota to oceanographic changes (Fig. 1c); and (5) changes in the geochemical properties of the inorganic shells of organisms, or bulk sediment, which can be calibrated against climatic variables, such as sea surface temperature (SST) (Fig. $1 \mathrm{~g}$ ), or used to evaluate marine productivity. Recently, the kinematic tracer protactinium/ thorium $(\mathrm{Pa} / \mathrm{Th})$ allowed reconstructing the state of the Atlantic Meridional Overturning Circulation (AMOC) in a more direct way than the benthic $\delta^{13} \mathrm{C}$ deep-water mass tracer (Fig. $1 \mathrm{~d}, \mathrm{e})$.

\section{Iceberg-rafted (Heinrich) Events}

Research in the 1970s and early 1980s in Baffin Bay and the Labrador Sea documented a series of detrital carbonate and ice-rafted debris (IRD) intervals, but the importance of these was not fully understood until after Heinrich's now classic paper on IRD-rich sediments in a series of cores in the mid-latitude NE Atlantic. Initially, these were interpreted in the context of the "orbital paradigm", but they are now recognized as a series of abrupt millennial-scale events that can be recognized on the basis of their sedimentology, mineralogy, geo- and biogeochemistry from the Labrador Sea south and east as far as the UK margin (Fig. 2). In 1992 these were referred to as "Heinrich events" (H-events), and in 1993 it was suggested that a connection existed between the Greenland Ice Sheet's Dansgaard-Oeschger (D-O) events and $\mathrm{H}$-events (Fig. 1a, b). The suggested link between D-O and H-events has resulted in a prolonged debate, not yet resolved, as to whether $\mathrm{H}$-events are a response to atmospheric climate, ocean climate, or internal ice sheet dynamics, or some combination.

What is known with certainty is $\mathrm{H}$ - events are sourced from glaciological collapse of the Laurentide Ice Sheet's (LIS) Hudson Strait Ice Stream. Hudson Strait H- events (HS H-) have a pacing of approximately 1 per $7.2 \mathrm{ky}$, with HSH-0 dated at $12 \mathrm{ka}, \mathrm{HSH}-1$ at $17 \mathrm{ka}, \mathrm{HSH}-2$ at $24.5 \mathrm{ka}$ etc. These catastrophic collapses of the LIS resulted in large-scale sediment and meltwater discharges into the Labrador Sea with a characteristic detrital carbonate (DC) signature (Fig. 1b). Icebergs transported sediments with diagnostic mineral and radiogenic signatures as far as 3000 to $4000 \mathrm{~km}$ South and East from Hudson Strait (Fig. 2a), whereas turbid glacial meltwaters cascaded down the slope below Hudson Strait, and then along the massive North Atlantic Mid-Ocean Channel (Fig. 2c). The primary mineral signature for the HS H-events is dolomite, especially in the North Atlantic sediment archives East of $45^{\circ} \mathrm{W}$, but in the ice-proximal setting off Hudson Strait the detrital carbonate sediments are dominated by calcite, with a calcite:dolomite ratio of $\sim 6: 1$. Across the North Atlantic, radiogenic ages and isotopic measurements on sediments within the various HS H-layers invariably indicate that the non-carbonate fine-fractions was derived from glacial erosion of the Archean bedrock that underlies and flanks Hudson Strait.

There is an ongoing and unresolved argument as to whether HS H-events triggered or were coeval with other millennial-scale IRD events in the Northern Hemisphere originating from different ice sheets or different sectors of the LIS. Discrete carbonate-rich IRD events have been described from cores retrieved from the Arctic Basin (Fig. 2b), and a series of detrital carbonate events have been identified in Baffin Bay (Fig. 2a). In the latter case, the Baffin Bay 
detrital carbonate (BBDC-) units, of which there are at least 8 within in the last glaciation, either lag the HS H-events by $\sim 2$ ky or have no obvious temporal correlation.

\section{Hydrographic Impacts of the Iceberg-rafted Events}

In the vicinity of the continental ice sheets, there is abundant evidence for discrete IRDrich events, some reflecting distal $\mathrm{H}$ - sedimentation (Fig. 2a), whereas others are linked to the Greenland or other ice sheets. Planktic foraminiferal $\delta^{18} \mathrm{O}$ records from sites off East Greenland, in the Norwegian Sea or from within the North Atlantic IRD belt (Fig. 2a) reveal abrupt changes, that -in particular during the $\mathrm{H}$ - events-are related to substantial surface-water freshening due to the melting icebergs. The freshwater, covering most of the North Atlantic greatly impacted the global oceanic and subsequently atmospheric circulation. With the glacial meltwater spreading into the North Atlantic, the location of the subpolar front was pushed southward leading to an expansion of the area (seasonally) covered by sea ice and to significantly colder sea-surface temperatures in the mid-latitudes (Fig. 1c). In addition, the freshwater cap hampered the formation of North Atlantic deep water (NADW), which resulted in reduced Atlantic Meridional Overturning Circulation (AMOC) (Fig. 1d) and spreading of Antarctic Bottom Water (AABW) upward into water depths otherwise occupied by NADW (Fig. 1e). Whereas the northern hemisphere experienced cooling, heat was retained in the southern hemisphere with maximum heat (Fig. 1h) and higher atmospheric carbon dioxide levels (Fig. 3i) occurring synchronous with the D-O events (rapid warming above Greenland; Fig. 1a, 3a). The AMOC strengthened at the same time, and the associated resumed northward transport of warm, saline waters led to cooling in the southern hemisphere. This interchange between northern and southern hemisphere variations is referred to as the bipolar seesaw. The youngest impression of the bipolar seesaw is the Antarctic Cold Reversal at the end of the last glacial period, when cooling occurred in Antarctica during the northern hemisphere's warm Greenland interstadial 1/Bølling (Fig. 1a, h). In the South Atlantic, warming was not only related to a reduced northward heat transport, but also to inflow of warmer, saline waters from the Indian Ocean into the South Atlantic, the Agulhas leakage (Fig. 1g).

Through the formation and spreading of AABW into the ocean basins, the signal of the Antarctic climate oscillations can also be found in deep-water records from the deep North Atlantic (Fig. 1f). Thus, at some locations in the North Atlantic, deep-water signals mimic Antarctic climate oscillations and surface-water signals Greenland variations. At intermediate depth levels, the Antarctic Intermediate Water (AAIW) also penetrated further northward into the global ocean basins during periods of a reduced AMOC.

\section{Impacts of the Iceberg-rafted Events on Hydrological and Biogeochemical Cycles}

In the same way as salinity variations in the modern ocean reflect changes in the hydrological cycle, that is - higher salinities are associated with increased evaporation and lower salinities with increased precipitation/melting of continental ice, the salinity changes associated with the millennial-scale changes influenced the glacial hydrological cycle. The low northern hemisphere temperatures together with the surface-water freshening and associated expansion of the sea-ice cover during the $\mathrm{H}$ - events resulted in a southward displacement of the Intertropical Convergence Zone (ITCZ), which impacted the hydrological cycle on a global scale. Many regions became drier (arid), forests contracted and monsoon systems like the East Asian summer monsoon (Fig. 3e), the Indian monsoon or the South American monsoon (Fig. 3d) became weaker, leading to less precipitation. In some regions, conditions also turned windier as best indicated by the increased dust flux from the deserts (Fig. 3c) and the formation of loess deposits. Nutrients delivered by dust to the adjacent oceans (e.g. iron, phosphate) and enhanced deep mixing due to stronger winds supported increased primary and export productivity in some regions, such as in the NW African upwelling system or in the 
subantarctic South Atlantic Ocean. However, in upwelling regions such as off Iberia, the Californian margin or in the Arabian Sea (Fig. 3b, f-h) productivity declined as consequence of the ITCZ's displacement. In the North Atlantic, the shallower winter mixed layer (related to the freshwater cap) hampered nutrient replenishment by deep mixing, leading to decreased productivity. On a global scale, marine productivity was diminished during $\mathrm{H}$ - events as response to the changes in the oceanic and atmospheric circulation patterns, with significant impacts on ecosystems and biogeochemical cycles (e.g., reduced denitrification in the Arabian Sea; Fig. 3f). In high productivity regions with oxygen minimum zones the lower productivity/carbon flux to the seafloor resulted in higher oxygen levels at the seafloor (Fig. $3 f, h)$.

\section{Millennial-scale periodicities?}

There is considerable discussion as to whether there are any predictable millennial-scale periodicities in ocean climate records, that are persistent and recurring during the Holocene and Quaternary. The most frequently mentioned candidate is a $\sim 1.5$ ky cycle that has potentially been detected in Holocene marine records from the Arctic Basin and some sites in the North Atlantic. However, there is no consensus on the underlying forcing, and whether there is such forcing, as the potential cyclicity has been attributed to "Stochastic resonance." Heinrich events 1 through 6 have a rather regular $\sim 7.2$ ky pacing, but the interval between $\mathrm{H}-$ 0 (Younger Dryas) and $\mathrm{H}-1$ is much shorter. The D-O events (Fig. 1a) at first glance appear to be evenly spaced, and in the Greenland $\delta 180$ record a prominent period of $\sim 1.47 \mathrm{ky}$ was observed. This period is, however, very much driven by the temporal spacing between D-O events/Greenland interstadials 4 and 7, in particular in the GISP2 chronology. Besides stochastic resonance, the possibility of there being a multiple of the de Vries/Suess solar cycle $(\sim 208$ y) has recently been proposed.

\section{Conclusions}

Millennial-scale changes have become an accepted reality in the climate system. Initial research concentrated on the massive changes associated with the discharge of sediments and water into the North Atlantic Ocean during the last glacial cycle (marine oxygen isotope stages 2-5) (Fig. 1, 2). High-resolution studies of our glacial world (Fig. 1, 3) indicate that similarly spaced events persisted in various, globally distributed climate archives, and that phasing between northern and southern hemispheric records was opposite (biploar seesaw). A number of publications have demonstrated that millennial-scale changes in various proxy records are a feature of ocean sediments over at least the last 800,000 years.

The work from tropical and subtropical sites (Fig. 1) indicates that Heinrich events have manifestations in ocean reconstructions, which belie a simple association with ice sheet instability and collapse. It is far from clear how oceanographic and atmospheric changes are transmitted to the bed of large ice streams, and there is indeed disagreement as to whether the collapse of northern hemisphere ice sheets (Fig. 2) was regionally coeval, or whether the collapses are linked temporally by a mechanism such as rapid changes in relative sea level. It has, however, been observed that the routing of fresh water can have dramatic effects, even in the present world, and the key may well lie in a better understanding of the role of the ocean thermohaline circulation system in the global climate system.

- Change history: June 2018. A. Voelker new 1st author. Abstract updated. Text expanded to include larger selection of proxies and new sections on the Hydrographic Impacts of the Iceberg-rafted Events and on the Impacts of the Iceberg-rafted Events on Hydrological and Biogeochemical Cycles. Three new figures replacing the previous figures. References updated and expanded. Supporting online information added. 


\section{Figure Captions:}

Figure 1: Paleoclimate records showing millennial-scale climate variations on Greenland, Antarctica and in the Atlantic Ocean. a) NGRIP $\delta^{18} \mathrm{O}$ record (50-yr resolution) with numbers marking some of the Greenland interstadials (Rasmussen et al., 2014); b) ice-rafted detrital carbonate maxima reveal Heinrich layers at DSDP Site 609 in the North Atlantic IRD belt (Obrochta et al., 2012 based on Bond et al., 1999); c) summer sea-surface temperature changes at the Iberian margin (core MD95-2040; Salgueiro et al., 2010; transferred to GICC05 chronology); d) $\mathrm{Pa} / \mathrm{Th}$ based reconstructions for AMOC strength based on a compilation of 4 different records (Henry et al., 2016 and references therein); e) deep-water mass changes as indicated by the benthic $\delta^{13} \mathrm{C}$ record of IODP Site U1308 (Hodell et al., 2008); f) the benthic $\delta^{18} \mathrm{O}$ record of core MD95-2042 (Iberian margin; Shackleton et al., 2000; transferred to GICC05 chronology); g) warmer $\mathrm{Mg} / \mathrm{Ca}$-based sea-surface temperatures at the location of core MD02-2594 (Agulhas Bank off southwest Africa; Dyez et al., 2014) indicate enhanced Agulhas leakage from the Indian Ocean into the South Atlantic; h) Antarctic temperature stack (based on Antarctic ice core stable isotope records) by Parrenin et al. (2013). AIM = Antarctic isotope maximum; $\mathrm{ACR}=$ Antarctic cold reversal. See multi-media annex for details on data sources and references.

Figure 2: Core sites with IRD signals during Heinrich events (published between 1978 and 2017); modified from Andrews and Voelker (2018). Inset on the right shows cores in the Arctic Ocean with reference to $\mathrm{H}$ - events. The dark gray dots mark the core sites studied by Ruddiman and define the ice-rafting belt (stippled area). Petrol-blue colored lines indicate IRD concentrations reconstructed by Ruddiman for the period from 25-40 ka, i.e. late Marine Isotope Stage 3 and encompassing $\mathrm{H}$ - event 3 and $\mathrm{H}$ - event 4, with numbers 200 and 50 (thinner line) denoting the respective concentrations [milligrams per square centimeter per $1000 \mathrm{y}$ ]. Black lines show the Last Glacial Maximum ice sheet extent. (inset on left): Close-up of the Labrador Sea with the North Atlantic Mid-Ocean Channel (NAMOC) and some feeder channels on the Canadian margin indicated by black lines.

Figure 3: Impacts of millennial-scale climate variations on hydrological and biogeochemical cycles. a) as in Fig. 1; b) planktonic foraminifera assemblage derived export productivity changes off Portugal (core MD95-2040; Salgueiro et al., 2010; transferred to GICC05 chronology); c) Aeolian dust concentrations recorded in core GeoB9508-5, Cape Blanc upwelling region (Collins et al., 2013). d) $\delta^{18} \mathrm{O}$ records of speleothems from caves in central eastern Brazil show drier conditions/failure of South American monsoon during H- events (Strikis et al, 2018). e) Combined $\delta^{18} \mathrm{O}$ record of Chinese speleothems point to weakened East Asian (summer) monsoon during cold millennial-scale climate periods (Cheng et al., 2016). f) Bulk sediment $\delta^{15} \mathrm{~N}$ record of core RC27-23 off Oman (Arabian Peninsula) reveals stronger denitrification (= higher productivity and less oxygen in waters at seafloor) during millennialscale warm climate periods (Altabet et al., 2002; transferred to GICC05 chronology). g) Changes in bulk sediment Nickel (Ni) concentration in core SO130-289KL, northeastern Arabian Sea, reflect changes in organic carbon flux to the seafloor and thus productivity in the surface waters above (Deplazes et al., 2014). h) Variations in the abundance of benthic foraminifera species associated with dysoxic environmental conditions reveal oxygen-content oscillations at the seafloor off southern Baja California (Mexico, E Pacific) (core MD02-2508; Tetard et al., 2017). i) Atmospheric carbon dioxide concentrations compiled from various sources (including Antarctic ice cores; Koehler et al., 2017). See multi-media annex for details on data sources and references. 


\section{Selected readings}

Alley, R.B., Anandakrishnan, S., Jung, P., 2001. Stochastic resonance in the North Atlantic. Paleoceanography 16, 190-198.

Alley, R.B., MacAyeal, D.R., 1994. Ice-rafted debris associated with binge-purge oscillations of the Laurentide Ice Sheet. Paleoceanography 9, 503-511.

Andrews, J.T., Kirby, M.E., Aksu, A., Barber, D.C., Meese, D., 1998. Late Quaternary Detrital Carbonate (DC-) events in Baffin Bay $\left(67^{\circ}-74^{\circ} \mathrm{N}\right)$ : Do they correlate with and contribute to Heinrich Events in the North Atlantic? Quaternary Science Reviews 17, 1125-1137.

Andrews, J.T., Tedesco, K., 1992. Detrital carbonate-rich sediments, northwestern Labrador Sea: Implications for ice-sheet dynamics and iceberg rafting (Heinrich) events in the North Atlantic. Geology 20, 1087-1090.

Andrews, J.T., Voelker, A., 2018. "Heinrich events" (\& sediments): A history of terminology and recommendations for future usage. Quaternary Science Reviews 187, 31-40.

Bond, G., Broecker, W.S., Johnsen, S., McManus, J., Labeyrie, L., Jouzel, J., Bonani, G., 1993. Correlations between climate records from North Atlantic sediments and Greenland ice. Nature 365, 143-147.

Bond, G., Heinrich, H., Broecker, W.S., Labeyrie, L., McManus, J., Andrews, J.T., Huon, S., Jantschik, R., Clasen, S., Simet, C., Tedesco, K., KLas, M., Bonani, G., Ivy, S., 1992. Evidence for massive discharges of icebergs into the glacial Northern Atlantic. Nature 360, 245-249.

Bond, G., Kromer, B., Beer, J., Muscheler, R., Evans, M.N., Showers, W., Hoffman, S., LottiBond, R., Hajdas, I., Bonani, G., 2001. Persistent solar influence on North Atlantic climate during the Holocene. Science 294, 2130-2136.

Bond, G.C., Lotti, R., 1995. Iceberg Discharges into the North Atlantic on Millennial Time Scales During the Last Glaciation. Science 267, 1005-1009.

Broecker, W.S., Bond, G., McManus, J., Klas, M., Clark, E., 1992. Origin of the Northern Atlantic's Heinrich events. Climate Dynamics 6, 265-273.

Darby, D.A., Ortiz, J.D., Grosch, C.E., Lund, S.P., 2012. 1,500-year cycle in the Arctic Oscillation identified in Holocene Arctic sea-ice drift. Nature Geoscience 5, 897-900.

EPICA Community Members (2006). One-to-one coupling of glacial climate variability in Greenland and Antarctica. Nature 444, 195-198.

Heinrich, H., 1988. Origin and consequences of cyclic ice rafting in the Northeast Atlantic Ocean during the past 130,000 years. Quat. Res. 29, 143-152.

Hemming, S.R., 2004. Heinrich Events: Massive late Pleistocene detritus layers of the North Atlantic and their global climate imprint. Reviews of Geophysics 42, RG1005/2004.

Henry, L.G., McManus, J.F., Curry, W.B. et al. (2016). North Atlantic ocean circulation and abrupt climate change during the last glaciation. Science 353, 470-474.

Hesse, R., 2016. Ice-proximal Labrador Sea Heinrich layers: a sedimentological approach. Canadian Journal of Earth Sciences 53, 71-100.

Hesse, R., Khodabakhsh, S., 2016. Anatomy of Labrador Sea Heinrich layers. Marine Geology $380,44-66$.

Jennings, A.E., Andrews, J.T., ÓCfoaigh, C., St. Onge, G., Sheldon, S., Belt, S.T., CabedoSanz, P., Hillaire-Marcel, C., 2017. Ocean forcing of Ice Sheet Retreat in Central West Greenland from LGM through Deglaciation. Earth and Planetary Science Letters 472, 1-13.

Manighetti, B., McCave, I.N., Maslin, M., Shackleton, N.J., 1995. Chronology for climatechange - developing age models for the biogeochemical ocean flux study cores. Paleoceanography 10, 513-525.

Mariotti, V., Bopp, L., Tagliabue, A., Kageyama, M., Swingedouw, D. (2012). Marine productivity response to Heinrich events: a model-data comparison. Climate of the Past 8, $1581-1598$ 
Pedro, J.B., Jochum, M., Buizert, C., He, F., Barker, S., Rasmussen, S.O., 2018. Beyond the bipolar seesaw: Toward a process understanding of interhemispheric coupling. Quaternary Science Reviews 192, 27-46.

Salgueiro, E., Voelker, A.H.L., de Abreu, L. et al. (2010). Temperature and productivity changes off the western Iberian margin during the last $150 \mathrm{ky}$. Quaternary Science Reviews 29, 680-695.

Shackleton, N.J., Hall, M.A., Vincent, E. (2000). Phase relationships between millennial-scale events 64,000-24,000 years ago. Paleoceanography 15, 565-569.

Simon, Q., Hillaire-Marcel, C., St-Onge, G., Andrews, J.T., 2014. North-eastern Laurentide, western Greenland and southern Innuitian ice stream dynamics during the last glacial cycle. Journal of Quaternary Science 29, 14-26.

Stokes, C.R., Clark, C.D., Darby, D.A., Hodgson, D.A., 2005. Late Pleistocene ice export events into the Arctic Ocean from the M'Clure Strait Ice Stream, Canadian Arctic Archipelago. Global and Planetary Change 49, 139-162.

Strikis, N.M., Cruz, F.W., Barreto, E.A.S. et al. (2018). South American monsoon response to iceberg discharge in the North Atlantic. Proceedings of the National Academy of Sciences, doi:10.1073/pnas.1717784115.

\section{Selected webpages}

National Centers for Environmental Information: www.ncdc.noaa.gov/dataaccess/paleoclimatology-data

World Data Center PANGAEA: www.pangaea.de 


\section{Description for Multi-media annex:}

References and data sources for paleoclimate records shown in Figures 1 and 3.

Multi-media annex for "Millennial-Scale Ocean Climate Variability" chapter

\section{References and data sources for records shown in Figures 1 and 3}

NGRIP (Fig. 1a, 3a):

Rasmussen, S.O., Bigler, M., Blockley, S.P., Blunier, T., Buchardt, S.L. et al. (2014). A stratigraphic framework for abrupt climatic changes during the Last Glacial period based on three synchronized Greenland ice-core records: refining and extending the INTIMATE event stratigraphy. Quaternary Science Reviews 106, 14-28.

additional reference:

Seierstad, I.K., Abbott, P.M., Bigler, M., Blunier, T., Bourne, A.J. et al. (2014). Consistently dated records from the Greenland GRIP, GISP2 and NGRIP ice cores for the past $104 \mathrm{ka}$ reveal regional millennial-scale $\delta^{18} \mathrm{O}$ gradients with possible Heinrich event imprint. Quaternary Science Reviews 106, 29-46.

Note on chronostratigraphy: $\mathrm{b} 2 \mathrm{k}=2000 \mathrm{AD}$ ages of GICC05 were converted to BP (before present $)=1950 \mathrm{AD}$ ages .

DATA Sources: https://www.ncdc.noaa.gov/paleo/study/2481

http://www.iceandclimate.nbi.ku.dk/data/

DSDP Site 609 (Fig. 1b)

Obrochta, S.P., Miyahara, H., Yokoyama, Y., Crowley, T.J. (2012). A re-examination of evidence for the North Atlantic '1500-year cycle' at Site 609. Quaternary Science Reviews 55, 23-33.

Bond, G.C., Showers, W., Elliot, M., Evans, M., Lotti, R. et al. (1999). The North Atlantic's 1-2 kyr climate rhythm: relation to Heinrich events, Dansgaard/ Oeschger cycles and the Little Ice Age, In: Clark, P.U., Webb, R.S., Keigwin, L.D. (eds.), Mechanisms of Global Climate Change at Millennial Time Scales. pp. 35-58. Washington, D.C.: AGU

Note on chronostratigraphy: Bond et al. age model was converted to GICC05 chronology by Obrochta et al. (2012).

DATA Source: https://doi.org/10.1594/PANGAEA.834701

MD95-2040 (Fig. 1c, 3b)

Salgueiro, E., Voelker, A.H.L., de Abreu, L., Abrantes, F., Meggers, H., Wefer, G. (2010). Temperature and productivity changes off the western Iberian margin during the last 150 ky. Quaternary Science Reviews 29, 680-695.

Note on chronostratigraphy: GISP2 based age model was converted to GICC05 chronology for Strikis et al. (2018) publication (see Brazilian speleothems below). Conversion followed Seierstad et al. (2014); for details see Strikis et al. (2018).

DATA Sources: https://doi.org/10.1594/PANGAEA.743087 https://doi.org/10.1594/PANGAEA.737142

$\mathrm{Pa} / \mathrm{Th}$ records (Fig. 1d)

References listed in order of records shown in figure going from youngest to oldest! 
McManus, J.F., Francois, R., Gherardi, J.-M., Keigwin, L.D., Brown-Leger, S. (2004). Collapse and rapid resumption of Atlantic meridional circulation linked to deglacial climate changes. Nature 428, 834-837.

Lippold, J., Grützner, J., Winter, D., Lahaye, Y., Mangini, A., Christl, M. (2009). Does sedimentary 231Pa/230Th from the Bermuda Rise monitor past Atlantic Meridional Overturning Circulation? Geophys. Res. Lett. 36, doi:10.1029/2009g1038068.

Henry, L.G., McManus, J.F., Curry, W.B., Roberts, N.L., Piotrowski, A.M., Keigwin, L.D., (2016). North Atlantic ocean circulation and abrupt climate change during the last glaciation. Science 353, 470-474.

Böhm, E., Lippold, J., Gutjahr, M., Frank, M., Blaser, P. et al. (2015). Strong and deep Atlantic Meridional Overturning Circulation during the last glacial cycle. Nature 517, 7376.

DATA Source: http://www.ncdc.noaa.gov/paleo/study/20248

IODP Site U1308 (Fig. 1e)

Hodell, D.A., Channell, J.E.T., Curtis, J.H., Romero, O.E., Röhl, U. (2008). Onset of 'Hudson Strait' Heinrich Events in the Eastern North Atlantic at the end of the Middle Pleistocene Transition ( 640 ka)? Paleoceanography 23, PA4218, doi:10.1029/2008PA001591.

DATA Source: https://www.ncdc.noaa.gov/paleo/study/10250

MD95-2042 (Fig. 1f)

Shackleton, N.J., Hall, M.A., Vincent, E. (2000). Phase relationships between millennialscale events 64,000-24,000 years ago. Paleoceanography 15, 565-569.

Note on chronostratigraphy: The GRIP related age control points of Shackleton et al. (2000) were converted to GICC05 ages using the NGRIP to GRIP conversion of Seierstad et al. (2014).

DATA Source: https://doi.org/10.1594/PANGAEA.700954

MD02-2594 (Fig. 1g)

Dyez, K. A., Zahn, R., Hall, I. R. (2014). Multicentennial Agulhas leakage variability and links to North Atlantic climate during the past 80,000 years. Paleoceanography 29, 1238 1248 .

DATA Source: https://www.ncdc.noaa.gov/paleo/study/17935

Antarctic temperature stack (Fig. 1h)

Parrenin, F., Masson-Delmotte, V., Köhler, P., Raynaud, D., Paillard, D. et al. (2013). Synchronous Change of Atmospheric $\mathrm{CO}_{2}$ and Antarctic Temperature During the Last Deglacial Warming. Science 339, 1060-1063.

Note: this stack includes data from five different ice cores (EDC, Vostok, Dome Fuji, TALDICE, and EDML).

DATA Source: https://doi.org/10.1594/PANGAEA.810188

GeoB9508-5 (Fig. 3c)

Collins, J.A., Govin, A., Mulitza, S., Heslop, D., Zabel, M. et al. (2013). Abrupt shifts of the Sahara-Sahel boundary during Heinrich stadials. Clim. Past 9, 1181-1191.

DATA Source: https://doi.org/10.1594/PANGAEA.820419 


\section{Brazilian speleothems (Fig. 3d)}

Stríkis, N.M., Cruz, F.W., Barreto, E.A.S., Naughton, F., Vuille, M. et al. (2018). South American monsoon response to iceberg discharge in the North Atlantic. Proceedings of the National Academy of Sciences, doi:10.1073/pnas.1717784115.

DATA Sources: https://www.ncdc.noaa.gov/paleo/study/13540 https://www.ncdc.noaa.gov/paleo/study/23510

Chinese speleothems (Fig. 3e)

Cheng, H., Edwards, R.L., Sinha, A., Spötl, C., Yi, L. et al. (2016). The Asian monsoon over the past 640,000 years and ice age terminations. Nature 534, 640-646.

DATA Source: https://www.ncdc.noaa.gov/paleo/study/20450

RC27-23 (Fig. 3f)

Altabet, M.A., Higginson, M.J., Murray, D.W. (2002). The effect of millennial-scale changes in Arabian Sea denitrification on atmospheric $\mathrm{CO}_{2}$. Nature 415, 159-162.

Note on chronostratigraphy: the original, GISP2 related age model was converted to GICC05 ages using the NGRIP to GISP2 conversion of Seierstad et al. (2014).

DATA Source: https://www.ncdc.noaa.gov/paleo/study/2617

\section{S0130-289KL (Fig. 3g)}

Deplazes, G., Lückge, A., Stuut, J.-B.W., Pätzold, J., Kuhlmann, H. et al. (2014). Weakening and strengthening of the Indian monsoon during Heinrich events and Dansgaard-Oeschger oscillations. Paleoceanography 29, 99-114. doi:10.1002/2013PA002509.

DATA Source: https://www.ncdc.noaa.gov/paleo/study/16277

MD02-2508 (Fig. 3h)

Tetard, M., Licari, L., Beaufort, L. (2017). Oxygen history off Baja California over the last 80 kyr: A new foraminiferal-based record. Paleoceanography 32, 246-264.

DATA Source: supplementary material Table 2 provided with original publication.

\section{Atmospheric carbon dioxide (Fig. 3i)}

Köhler, P., Nehrbass-Ahles, C., Schmitt, J., Stocker, T.F., Fischer, H. (2017). A 156 kyr smoothed history of the atmospheric greenhouse gases $\mathrm{CO}_{2}, \mathrm{CH}_{4}$, and $\mathrm{N}_{2} \mathrm{O}$ and their radiative forcing. Earth System Science Data 9(1), 363-387.

DATA Source: https://doi.org/10.1594/PANGAEA.871265 


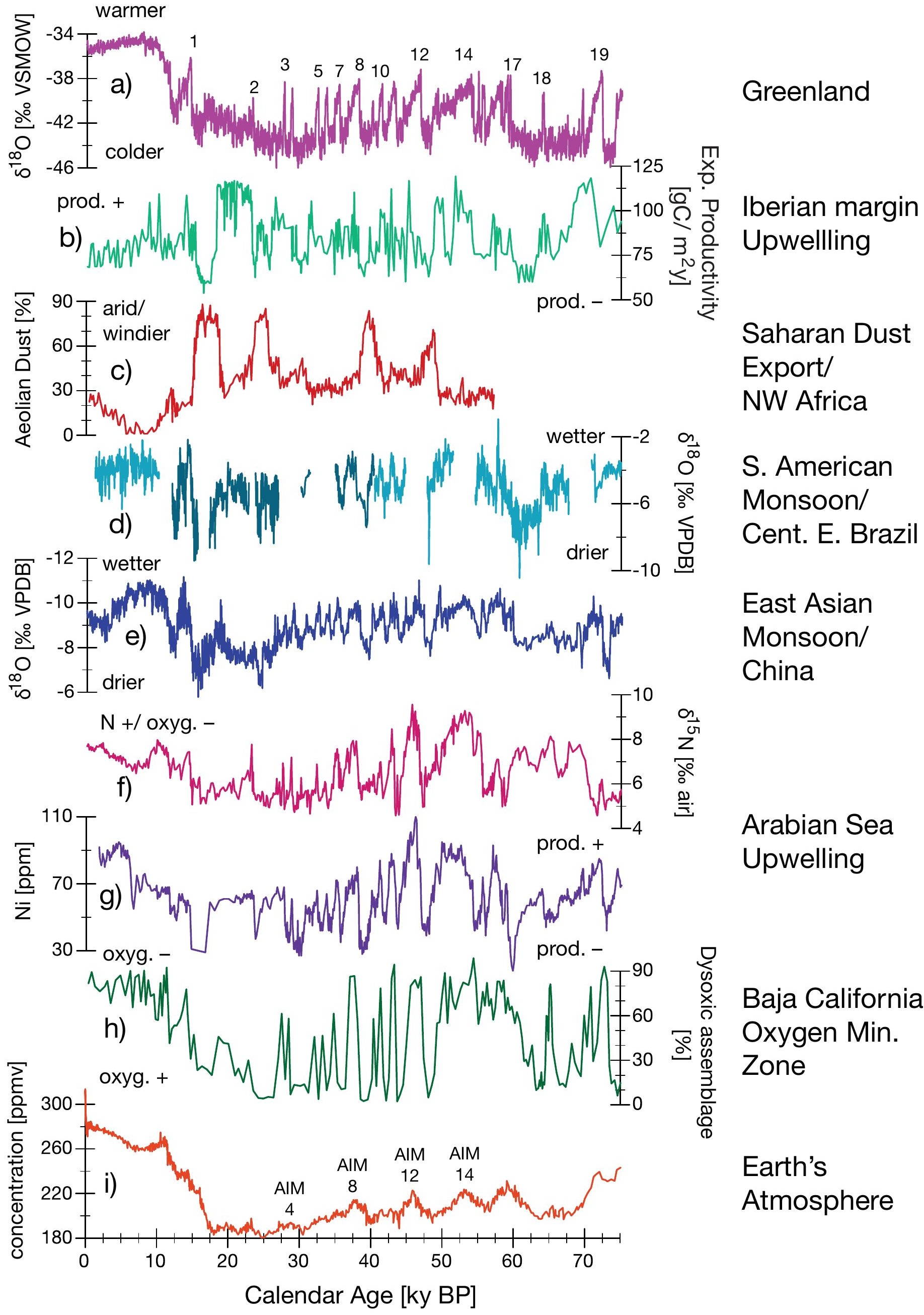

